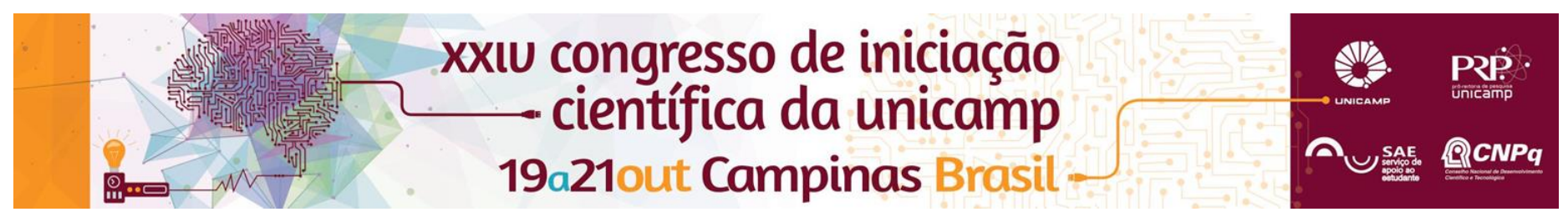

\title{
PREPARAÇÃO E ESCALAMENTO DE VIOLACEÍNA E SEU USO COMO PIGMENTO NATURAL EM TECIDOS
}

\author{
Caroline A. D. Rampazo ${ }^{1 *}$, Nelson Durán ${ }^{1,2}$ \\ ${ }^{1}$ Instituto de Química, Lab. Quím. Biol., UNICAMP. Campinas, SP, ${ }^{2}$ LNNano (CNPEM), Campinas. SP.
}

\begin{abstract}
Resumo
Nos ambientes hospitalares, podem ser encontrados diversos materiais têxteis, como cortinas, roupas de cama, batas cirúrgicas, uniformes, dentre outros. Como se sabe, tanto os tecidos feitos com fibras naturais quanto os produzidos com fibras sintéticas são susceptíveis ao crescimento de microrganismos. Deste modo, se este material for contaminado por microrganismos patogênicos, com grande incidência no ambiente hospitalar, ele se torna uma grande fonte de transmissão desses agentes infecciosos. Com o objetivo de diminuir fontes de contaminações hospitalares, este trabalho consistiu na preparação de um tecido com propriedades antibacterianas, utilizando o método padding para impregnar nanopartículas poliméricas contendo violaceína, um agente bactericida, em suas fibras. A violaceína usada neste projeto foi produzida por microrganismos da cepa Chromobacterium violaceum CCT 3468 em um biorreator tipo BPS (Biorreator de Prateleira para Superfície), e extraída com o uso de etanol P.A. A violaceína foi purificada por extração em soxlet utilizando clorofórmio, éter etílico e etanol como solventes, e caracterizada pelas técnicas de espectroscopia na região do infravermelho (ATR-FTIR), Ressonância Magnética Nuclear (RMN), Espectrometria de Massas (MS) e espectrofotometria na região do UV-vis. As nanopartículas poliméricas (NPs), por sua vez, foram produzidas pelo método de nanoprecipitação, e caracterizadas quanto ao diâmetro médio ( $Z_{\text {ave }}$ ), índice de polidispersidade (PDI) e Potencial Zeta (PZ). Os tecidos impregnados com nanopartículas contendo violaceína tiveram sua atividade antibacteriana avaliada pelo método de difusão em ágar. Os resultados mostraram que a violaceína obtida possui um grau de pureza de $73,40 \%$, as nanopartículas produzidas têm $Z_{\text {ave }}$ em torno de $184 \mathrm{~nm}$, PDI menor que 0,15 e PZ menor que $-14 \mathrm{mV}$ e a atividade antibacteriana do tecido mostrou-se eficaz para a inibição das bactérias, Staphylococcus aureus e Staphylococcus epidermides.
\end{abstract}

Palavras-chave: Violaceína, Nanopartículas, Tecidos.

\section{Introdução}

Uma das áreas que mais precisam ser atualizadas em novos produtos antimicrobianos é a área da saúde, devido ao alto índice de infecções hospitalares provenientes de microrganismos, que em muitos casos, são resistentes aos antibióticos tradicionais ${ }^{1}$. Assim, com o intuito de melhorar a qualidade de vida dos seres humanos, novos materiais estão sendo desenvolvidos com a finalidade de diminuir estas infecções ${ }^{2}$. Dentro desta classe de materiais encontram-se os produtos têxtis. Com foco nesta linha de pesquisa, o objetivo deste trabalho consistiu em realizar a produção de um tecido antimicrobiano a partir da impregnação de nanopartículas poliméricas, contendo violaceína, utilizando-se o método padding, que consiste em impregnar as NPs com o auxílio de dois rolos de compressão.

\section{Resultados e Discussão}

A violaceína foi obtida com uma pureza de $73,40 \%$. Sua obtenção foi comprovada pelas técnicas de ATR-FTIR, RMN, MS e UV-vis, onde os espectros apresentaram picos e bandas características deste composto, como pode ser observado no espectro de ATR-FTIR apresentado na Fig. 1. As NPs mostraram Zave em torno de $184 \mathrm{~nm}$, PDI menor que 0,15 e PZ menor que $-14 \mathrm{mV}$. A atividade antibacteriana do tecido mostrou-se eficaz para a inibição de duas bactérias, a $S$. Aureus e a $S$. Epidermides. Testes de comparação da atividade antibacteriana entre a violaceína encapsulada e a violaceina livre estão sendo realizados e os resultados ainda estão em estudo.

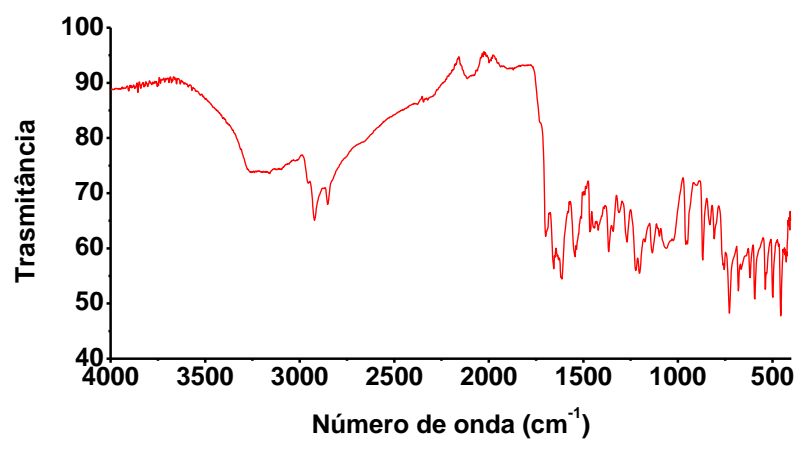

Figura 1. Espectro de infravermelho (ATR-FTIR) da violaceína produzida a partir da cepa Chromobacterium violaceum CCT 3468.

\section{Conclusão}

A violaceína encapsulada em nanopartículas poliméricas apresentou atividade contra bactérias quando impregnadas nas fibras de tecidos. A violaceína foi obtida com sucesso pela cepa Chromobacterium violaceum CCT 3468.

\section{Agradecimentos}

Agradeço a UNICAMP, ao programa PIBIC e ao CPQBA e sua equipe do laboratório de microbiologia.

\footnotetext{
${ }^{1}$ Durán, M.; Ponezi, A.N.; Faljoni-Alario, A.;Teixeira, M.F.S.; Justo, G.Z; Durán, N. Potential applications of violacein: A microbial pigment. Med.Chem. Res 21, 1524-1532 (2012)

${ }^{2}$ Cazoto, L.L.; Martins, D.; Ribeiro, M.G.; Durán, N.; Nakazato, G. Antibacterial activity of the violacein against Staphylococcus aureus isolated from Bovine mastitis. J. Antibiotics. 64, 395-397 (2011).
} 